\title{
Kajian Produksi Karkas Dan Non Karkas Ayam Kampung Dengan Pemberian Ransum Komersial Tersubstitusi Tepung Kulit Biji Kedelai
}

\author{
Sari $^{1 *}$, Harapin Hafid ${ }^{2}$, Andi Murlina Tasse ${ }^{2}$ \\ ${ }^{1}$ Mahasiswa Peternakan Program Pascasarjana UHO Kendari \\ ${ }^{2}$ Dosen Fakultas Peternakan Universitas Halu Oleo, Jl. Mokodompit, Kendari \\ Email : harapinhafid14@gmail.com
}

\begin{abstract}
ABSTRAK
Penelitian telah dilakukan untuk mengkaji efek pemberian ransum komersial tersubtitusi tepung kulit biji kedelai (TKBK) terhadap produksi karkas dan non karkas pada ayam kampung. Ayam kampung sebanyak 16 ekor berumur 7 minggu yang berasal dari ayam yang telah diberi perlakuan P0 (0\% TKBK), P1 (10\% TKBK), P2 (20\% TKBK) dan P3 (30\% TKBK) masingmasing 4 ekor sehingga rancangan yang digunakan rancangan acak lengkap. Sidik ragam digunakan untuk analisis data dilanjutkan dengan uji jarak berganda Duncan untuk melihat perbedaan pengaruh antar perlakuan. Bobot potong (g/ekor) tertinggi yang dihasilkan $529.0(\mathrm{P} 2)$ di ikuti dengan $484.0(\mathrm{P} 3), 452.0(\mathrm{P} 1)$ dan terendah 402.0 (P0). Bobot karkas (g/ekor) tertinggi yang dihasilkan $421.50(\mathrm{P} 2)$, diikuti 370.75 (P3), $331.50(\mathrm{P} 1)$ dan terendah 85.50 (P0). Persentase karkas (\%) tertinggi 79,69 (P2), 76,64 (P3) diikuti 73,39 (P1), 71,42 (P0). Bobot non karkas (g/ekor) 116.5-113.25 (P0-P3) dan persentase non karkas (\%) tertinggi 26,68 (P1), 25,58 (P0), 23,36 (P3) dan terendah 20,31 (P2). Bobot rempela (g/ekor) 4.00 (P0), 18.00 (P1), 17.50 (P2) dan 14.50 (P3). Persentase rempela (\%) 3,71 (P0), 3,99 (P1), 3,31 (P2) dan 3,00 (P3). Bobot hati (g/ekor) 42.00(P0), 13.50 (P1), 15.00 (P2) dan 12.00 (P3). Persentase hati (\%) 2,98 (P0), 2,97 (P1), 2,85 (P2) dan 2.48 (P3). Bobot jantung (g/ekor) 2.00 (P0), 2.00 (P1), 2.50 (P2) dan 2.00 (P3). Persentase jantung (\%) 0,50 (P0),0,45 (P1), 0,47 (P2) dan 0,42 (P3). Kesimpulan dari hasil penelitian bahwa pemberian ransum komersial tersubtitusi $10-30 \%$ tepung kulit biji kedelai (TKBK) dapat meningkatkan performa karkas tetapi tidak mempengaruhi secara nyata performa non karkas (giblet) pada ayam kampung.
\end{abstract}

Kata kunci: tepung kulit biji kedelai, karkas, non karkas, giblet, ayam kampung.

\section{ABSTRACT}

The study was conducted to find out the effect of fed commercial ration substituted soybean shell meal (SSM) on native chickens carcass and non carcass weight and percentage. Sixteen native chicken aged 7 weeks and was treatmented T0 (0\% SSM), T1 (10\% SSM), T2 (20\% SSM) and T3 (30\% SSM) each. 4 chickens. The study used a completely randomized design (CRD). Data obtained were analyzed using a analysis of variance (ANOVA) and then was continued with Duncans multiple range test (DMRT). Results of the study showed that slaughter weights (SW, g/chicken) are highest 529.0 (T2) followed with 484.0 (T3), 452 (T1) and lowest 402.0 (TO). Carcass Weights (CW, g/chicken) are highers 421.50 (T2), followed with 370.75 (T3), 331.50 (T1) and lowest 285.50 (T0). Carcass percentages (CP, \%) are highest 76.69 (T2), 76.64 (T3) followed with 73.39 (T1), 71.42 (T0). Non carcass weights (NCW, g/chicken) 116.50113.25 (T0-T3) and non carcass percentage (NCP, \%) are highest 26.68 (T1), 25.58 (T0), 23.36 (T3) and lowest 20.31 (T2). Gizzard weights (GW, g/chicken) are 14.00 (T0), 18.00 (T1), 17.50 (T2) and 14.50 (T3). Gizzard percentages (GP, \%) are 3.71 (T0), 3.99 (T1), 3.31 (T2) and 3.00 (T3). Liver weights (LW, g/chicken) are 12.00 (T0), 13.50 (T1), 15.00 (T2) and 12.00 (T3). Liver percentages (LP, \%) are 2,98 (T0), 2,97 (T1), 2.85 (T2) and 2.48 (T3). Heart weights (HW, g/chicken) was 2.00 (T0), 2.00 (T1), 2.50 (T2) and 2.00 (T3). Heart percentages (HP,\%) are 0.50 (T0), 0.45 (T1), 0,47 (T2) and 0.42 (T3). The conclusion of the study that fed commercial ration substituted soybean shell meal improved carcass performa but non significantly influence non carcass (viscera) performance native chicken. 
Key words: soybean, shell meal, carcass, non-carcass, viscera, native chicken

\section{PENDAHULUAN}

\section{Latar Belakang}

Ayam kampung merupakan ayam lokal di Indonesia yang kehidupannya sudah lekat dengan masyarakat. Ayam kampung memiliki kemampuan pada daya adaptasi yang tinggi karena mampu menyesuaikan diri dengan berbagai situasi, kondisi lingkungan dan perubahan iklim serta tahan terhadap penyakit (Pagala $d k k, 2013)$. Kondisi utama dalam pengembangan ayam kampung adalah rendahnya produktivitas, baik dalam menghasilkan telur maupun bobot potong.

Karkas bernilai ekonomi tinggi karena dari karkas diperoleh daging yang merupakan bahan pangan bernilai gizi tinggi dan harganya lebih mahal.Sedangkan bagian non karkas yang biasa disebut offals terdiri atas bagian yang layak dimakan dan bagian tidak layak dimakan.Di Indonesia bagian ayam kampung tidak layak dimakan seperti bulu, darah dan kaki, sedangkan bagian layak dimakan seperti kepala dan leher, rempela, hati, jantung, limfa dan usus.

Rendahnya produktifitas ayam kampung dipengaruhi oleh beberapa faktor diantaranya Umur dan pakan. Pakan merupakan salah satu faktor penting untuk meningkatkan produktivitas dari ayam kampung baik produksi karkas dan non karkas, bila diberi pakan yang baik dengan kandungan nutrient zat-zat makanan yang sesuai dengan kebutuhan hidup pokok dapat meningkatkan pertambahan bobot hidup ayam kampung lebih cepat, hal ini berhubungan dengan terekspresinya gen cGH dengan baik pada ayam lokal (Pagala $d k k, 2015$ ). Bahan pakan yang biasa digunakan dalam penyusunan ransum ayam kampung merupakan ransum komersial dan mempunyai harga yang relatif mahal karena masih impor untuk memenuhi kebutuhan dalam negeri.Harga bahan pakan yang relatif mahal dapat meningkatkan biaya pakan. Oleh karena itu perlu dicari bahan pakan inkonvensional yang mengandung nutrisi yang cukup dan tidak bersaing dengan kebutuhan manusia dan harganya relatif murah.

Salah satu bahan yang memiliki kriteria tersebut adalah limbah atau hasil ikutan industri pengolahan kedelai berupa kulit arikedelai atau kulit biji kedelai .Kulit biji kedelai mempunyai potensi pemanfaatan yang lebih tinggi karena belum termanfaatkan secara optimal bila dibandingkan dengan ampas tahu dan relatif mudah didapatkan daripada tepung azola. Kulit ari biji kedelai merupakan limbah yang berpotensi untuk bahan campuran ransum ternak unggas dan pakan ikan (Yefri, 2006). Menurut Gunawan, et al. (2003), kulit ari kedelai (Glycine max L. Merril) dalam 91,41 \% kadar kering terdapat protein kasar $21,13 \%$, lemak kasar 3,029, dan serat kasar sebanyak 23,18 \%. Dengan subtitusi jumlah pada formulasi ransum dapat berpotensi merubah kandungan nutrisi dan mengurangi biaya untuk pakan.

Hasil penelitian mengenai penggunaan limbah pengolahan kedelai seperti tepung kulit biji kedelai (TKBK)untuk perbaikan produksi karkas dan non karkas ayam kampung belum banyak ditemukan dalam jurnal ilmiah,Oleh karena itu, perlu dilakukan penelitian untuk mengkaji efek pemberian ransum komersial tersubtitusi tepung kulit biji kedelai terhadap produksi karkas dan non karkas ayam 
kampung.

\section{Tujuan Penelitian}

Penelitian ini bertujuan untuk :

1) Mengkaji produksi karkas meliputi bobot dan persentase karkas dan bagian-

bagian karkas (paha, dada, punggung dan sayap) ayam kampung dengan pemberian ransum komersial tersubtitusi tepung kulit biji kedelai.

2) Mengkaji produksi non karkas meliputi bobot dan persentase giblet (jantung, hati dan rempela) ayam kampung dengan pemberian ransum komersial tersubtitusi tepung kulit biji kedelai.

\section{TINJAUAN PUSTAKA}

\section{Deskripsi Teori}

\section{Karakteristik Ayam Kampung}

Ayam kampong yang banyak dipelihara sekarang ini secara genetis diperkirakan berasal dari keturunan ayam hutan merah (Gallus-gallus) dan ayam hutan hijau (Gallus-varius). Akibat proses budidaya dan pengaruh lingkungan hidup yang berbeda-beda, terbentuklah beragam varietas dan tipe ayam. Masing-masing memiliki fisik dan sifat genetik yang berbeda. Kelompok Gallus domesticus ini dibedakan menjadi ayam buras (ayam kampung) dan ayam ras (Iswanto,2008).

Berat badan ayam kampung untuk betina dewasa sekitar 2,5 $\mathrm{kg}$ dan jantan 3-3,5 kg. Ayam kampung disebut ayam lokal karena sering diberi nama sesuai dengan daerah asalnya, misalnya ayam sumatera, ayam kedu, ayam nunukan dan ayam pelung. Ayam buras yang dipelihara secara tradisional akan mengalamai tiga kali penetasan dalam setahun dengan jumlah anak setiap penetasan rata-rata 10 ekor. Ada beberapa jenis ayam buras, mulai dari tipe ringan sampai tipe berat dengan berat badan 1,5 kg (Koswara, 2009).

\section{Kulit Biji Kedelai}

Kulit ari biji kedelai kaya akan kandungan protein dan serat kasar yang baik untuk ternak unggas. Kandungan protein pada kulit ari kedelai mencapai 43-48\%.Selain itu juga mengandung zat anti nutrisi seperti tripsin inhibitor yang dapat mengganggu pertumbuhan unggas, namun zat tersebut dapat rusak oleh pemanasan sehingga aman untuk pakan ternak. Zat penting lain yang terkandung dalam kulit ari biji kedelai adalah serat kasar yang baik untuk pakan ternak. Namun serat kasar tersebut belum dapat dicerna secara langsung oleh ternak sehingga harus diolah terlebih dahulu (Niswati, dkk., 2009).

Kulit biji kacang kedelai (ampas tempe) mempunyai kandungan zat nutrisi cukup tinggi yaitu mengandung protein $11,45-12,44 \%$, serat kasar 34,74-42,29\%, lemak kasar 2,67-4,03\% dalam bahan kering. Selain itu mengandung asam amino metionin sebesar 0,4\% dan lisin 0,2\%. Kandungan proteinnya hampir sama dengan dedak padi, tetapi serat kasarnya cukup tinggi. Kandungan serat kasar yang tinggi merupakan faktor pembatas untuk menggunakan kulit biji kedelai dalam jumlah besar (Suci dan Sumiati, 1995).

Salah satu bahan pakan sumber protein nabati dan energi yang selalu digunakan untuk penyusunan pakan ternak unggas adalah bungkil kedelai dan jagung, karena mengandung protein kasar dan energy metabolis yang tinggi, tetapi harganya relative mahal dan masih diimpor untuk memenuhi 
kebutuhan dalam negeri. Untuk itu perlu dicari bahan pakan inkonvensional yang mengandung zat-zat makanan yang cukup dan tidak bersaing dengan kebutuhan manusia (Nelwida, 2011)

\section{METODE PENELITIAN}

\section{Waktu dan Lokasi Penelitian}

Penelitian ini dilaksanakan selama 2 bulan yaitu daribulan Februari sampai Maret 2016. Penelitian ini dibagi dalam 2 tahap yaitu tahap awal pemeliharaan untuk pembiasaan pakan pada ayam kampung umur 1-14 hari dan tahap pengambilan data umur 7 minggu (ayam pada fase pertumbuhan). Pemeliharaan ayam selama penelitian bertempat di Kandang Ayam Kampung Laboratorium Ilmu dan Teknologi Produksi Ternak,

\section{Materi Penelitian}

\section{Bahan Penelitian}

Bahan yang digunakan untuk penelitian ini terdiri atas 64 ekor ayam kampung umur dua bulan (grower), petakan kandang litter berukuran 1 x 1 $\mathrm{m}^{2}$, lampu penerang, peralatan tempat makan dan minum, timbangan pakan, timbangan digital, gelas ukur air minum, kantong kresek, tabel pengamatan, stiker, seperangkat alat pemotongan dan pengkarkasan, alat tulis menulis, plastik alas, dan kamera.

\section{Pelaksanaan Penelitian}

\section{Persiapan Kandang}

Sebelum digunakan seluruh kandang dan peralatannya disucihamakan terlebih dahulu menggunakan antiseptik untuk mencegah kontaminasi mikroorganisme merugikan. Penempatan ayam dalam petak percobaan dilakukan secara acak dan tiap petak kandang terdiri dari 4 ekor ayam.

\section{Penyusunan Ransum}

Ransum yang digunakan untuk penelitian terdiri atas jagung, giling ransum komersialdan tepung kulit biji kedelai dipersiapkan sesuai dengan perlakuan.

Table 1. Komposisi Kimia Pakan yang digunakan dalam menyusun ransun penelitian

\begin{tabular}{|c|c|c|c|c|}
\hline Pakan & $\begin{array}{l}\text { Air } \\
(\%)\end{array}$ & $\begin{array}{c}\text { Protein } \\
\text { Kasar } \\
(\%)\end{array}$ & $\begin{array}{c}\text { Lemak } \\
\text { Kasar( } \\
\%)\end{array}$ & $\begin{array}{c}\text { Serat } \\
\text { Kasar } \\
(\%)\end{array}$ \\
\hline $\begin{array}{l}\text { Ransum } \\
\text { Komersil }^{1}\end{array}$ & 13,00 & 20,00 & 3,00 & 6,00 \\
\hline Jagung $^{2}$ & 14,48 & 10,63 & 4,25 & 1.49 \\
\hline $\mathrm{TKBK}^{3}$ & $5,02^{3 \mathrm{~b}}$ & $34,90^{3 a}$ & $5,5^{3 \mathrm{a}}$ & $7,06^{3 \mathrm{~b}}$ \\
\hline $\begin{array}{l}{ }^{1} \text { PT. C } \\
{ }^{2} \text { Nelwi } \\
{ }^{3 a} \text { Nurr } \\
{ }^{3 b} \text { Has } \\
\text { Univer }\end{array}$ & $\begin{array}{l}\text { haroen } \mathrm{F} \\
\text { ta } 2011 \\
\text { chana et } \\
\text { 1. Anali } \\
\text { itas Hal }\end{array}$ & $\begin{array}{l}\text { okphand I } \\
\text { al., } 2002 \\
\text { is Labor } \\
\text { Oleo Ke }\end{array}$ & lonesia & Terpadu \\
\hline
\end{tabular}

Taraf pemberian tepung kulit biji kedelai yang digunakan untuk penelitian yaitu:

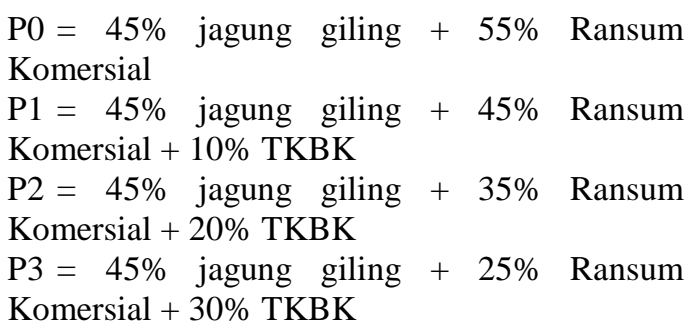

Komposisi kimia ransum penelitian dapat dilihat pada Tabel 1.

Tabel 2. Komposisi Kimia Ransum Penelitian $^{1}$

\begin{tabular}{ccccc}
\hline Perlakuan & $\begin{array}{c}\text { Air } \\
(\%)\end{array}$ & $\begin{array}{c}\text { Protein } \\
\text { Kasar } \\
(\%)\end{array}$ & $\begin{array}{c}\text { Lemak } \\
\text { Kasar } \\
(\%)\end{array}$ & $\begin{array}{c}\text { Serat } \\
\text { Kakar } \\
(\%)\end{array}$ \\
\hline P0 & 11,79 & 13,66 & 3,07 & 3,44 \\
P1 & 11,13 & 15,23 & 3,33 & 3,07 \\
P2 & 10,42 & 17,66 & 3,50 & 4,13 \\
P3 & 9,82 & 20,05 & 3,65 & 4,67
\end{tabular}

${ }^{1}$ Hasil perhitungan berdasarkan komposisi kimia pakan dari pakan formulasi ransum.

\section{Persiapan Kandang}

Petak kandang berukuran $1 \mathrm{~m}$ x $1 \mathrm{~m} x$ $1,5 \mathrm{~m}$ dengan sistem litter 16 
petak.Sebelum digunakan seluruh kandang dan peralatannya disucihamakan terlebih dahulu.Selanjutnya lantai kandang diisi sekam padi sebagai alas kandang. Perlakuan ayam kampung ditimbang untuk memperoleh bobot badan awal yang homogen sebanyak 64 ekor dan secara kelompok ke dalam petak masing-masing 4ekor .

\section{Pelaksanaan Penelitian}

\section{Pemeliharaan Ayam}

Ayam kampung dipelihara sejak DOC sampai umur 7 minggu.Air minum diberikan secara ad libitum. Ransum perlakuan diberikan pada ayam umur 3-7 minggu.

\section{Prosedur Pemotongan dan Pengkarkasan}

Ayam dipotong pada umur 7 minggu. Sebelum pemotongan ayam dipuasakan selama 8 jamdari pakan untuk menghindari bias akibat isi saluran pencernaan. Kemudian ayam ditimbang untuk mengetahui bobot hidupnya.Pemotongan ayam dilakukan pada bagian arteri karotis, vena jugularis, tenggorokan dan esophagus.

Setelah dipotong ayam digantung dengan tujuan untuk mempercepat proses pengeluaran darah. Setelah darah keluar ayam dicelupkan ke dalam air panas, lalu dikeringkan selama 3 menit. Pencabutan bulu dilakukan dengan caramencabut semua bulu yang melekat pada ayam. Selanjutnya dilakukan pengeluaran jeroan, kepala, leherdan kakinya dipotong sehingga yang ada hanya bagian karkas.Karkas yang diperoleh ditimbang dengan timbangan digital.

\section{Rancangan Penelitian}

Rancangan penelitian
digunakan adalah
Lengkap dengan 4 perlakuan dan 4
ulangan, masing-masing ulangan

diwakili satu ekor ayam.Sehingga jumlah sampel ayam kampung yang digunakan untuk penelitian sebanyak 16 ekor.

Model matematika mengacu pada Steel dan Torrie (1993) yaitu :

$$
\mathrm{ij}=\mu+\alpha \mathrm{i}+\mathrm{ij}
$$

\section{Variabel Penelitian}

Variabel yang diamati dalam penelitian ini adalah sebagai berikut :

1. Bobot Potong $(\mathrm{g})$

Bobot potong dapat diperoleh dengan cara menimbang ayam kampung yang telah dipuasakan sebelum pemotongan.

2. Bobot Karkas (g)dan Persentase karkas (\%)

- Bobot karkas adalah bobot ayam setelah dipotong yang telah dikurangi dengan darah, bulu, kepala dan leher, kaki dan organ pencernaan.

Nilai persentase karkas
diperoleh
membandingkan bobot karkas
dengan bobot potong dikali
$100 \%$.

3. Bobot (g) dan Persentase Bagianbagian Karkas (\%)

Nilai persentase bagian-bagian karkas (paha, dada, punggung dan sayap) diperoleh dengan membandingkanmasing-masing bagian-bagian karkas dengan bobot karkas dengan bobot potong dikali $100 \%$

4. Bobot (g) dan Persentase Giblet (\%)

Bobot Giblet diperoleh dengan cara menimbang organ dalam yang dikeluarkan saat perhitungan nonkarkas meliputi; rempela, hati dan jantung. Persentase giblet diperoleh dari perhitungan yaitu 
bobot giblet dibagi dengan bobot potong dan dikali $100 \%$.

\section{Analisis Data}

Analisis ragam digunakan untuk mengetahui pengaruh perlakuan terhadap variabel yang diamati. Jika perlakuan nyata terhadap variabel yang diukur maka akan diuji lanjut dengan uji jarak bergandaDuncan yang mengacu pada Steel dan Torrie (1993).

\section{HASIL DAN PEMBAHASAN}

\section{Pengaruh Pemberian Tepung Kulit Biji Kedelai terhadap Performans Karkas dan Non karkas Ayam Kampung}

Performans ayam kampung sebelum dan setelah pemotongan ditunjukkan dengan bobot potong (bobot hidup sebelum ayam disembelih), bobot dan persentase karkas, bobot dan persentase non karkas.Performans karkas ayam kampung sebelum pemotongan ditunjukkan dengan bobot potong.

Bobot potong merupakan bobot badan darihasil penimbangan ayam kampung sesaat sebelum pemotongan juga sering disebut bobot hidup.Bobot karkas merupakan bobot ayam setelah pemotongan saluran pernapasan, tenggorokan, pembuluh darah dan leher, pengeluaran darah, pelepasan bulu, pemotongan kaki kepala dan leher, dan pengeluaran organ dalam.Persentase persentase karkas merupakan perbandingan antar bobot karkas dengan bobot potong. Bobot non karkas merupakan bobot dari bagian selain karkas.Persentase bobot non karkas merupakan perbandingan antara bobot non karkas dengan bobot potong.

Rataan bobot potong, bobot dan persentase karkas, bobot dan persentase non karkas ayam kampung dengan pemberian tepung kulit biji kedelai (TKBK) disajikan pada Tabel 3.

Tabel 3. Rataan bobot potong, bobot dan persentase karkas, bobot dan persentase non karkas pada ayam kampung dengan pemberian tepung kulit biji kedelai (TKBK)

\begin{tabular}{lcccc}
\hline \multirow{2}{*}{\multicolumn{1}{c}{ Variabel }} & \multicolumn{4}{c}{ Perlakuan } \\
\cline { 2 - 5 } & P0 & P1 & P2 & P3 \\
& $(0 \%$ TKBK $)$ & $(10 \%$ TKBK $)$ & $(20 \%$ TKBK $)$ & $(30 \%$ TKBK $)$ \\
\hline Bobot potong (g/ekor) & $402,0^{\mathrm{d}}$ & $452,5^{\mathrm{c}}$ & $529,0^{\mathrm{a}}$ & $484,0^{\mathrm{b}}$ \\
Bobot karkas (g/ekor) & $285,50^{\mathrm{d}}$ & $331,50^{\mathrm{c}}$ & $421,50^{\mathrm{a}}$ & $370,75^{\mathrm{b}}$ \\
Persentase karkas (\%) & $71,42^{\mathrm{b}}$ & $73,39^{\mathrm{b}}$ & $79,69^{\mathrm{a}}$ & $76,64^{\mathrm{a}}$ \\
Bobot non karkas (g/ekor) & 116,5 & 117,0 & 107,5 & 113,25 \\
Persentasenonkarkas (\%) & $25,58^{\mathrm{a}}$ & $26,68^{\mathrm{a}}$ & $20,31^{\mathrm{b}}$ & $23,36^{\mathrm{ab}}$ \\
\hline
\end{tabular}

a,b,c,d superskrip berbeda pada baris yang sama menunjukkan berpengaruh nyata $(\mathrm{P}<0,05)$

\section{Bobot Potong}

Tabel 3 menunjukkan pemberian $10 \%$ (P1), 20\% (P2) dan 30\% (P3) TKBK dalam ransum secara nyata meningkatkan bobot potong ayam kampung. Bobot potong yang diperoleh dari pemberian $20 \%$ TKBK sebesar 529,0 g/ekor merupakan bobot potong tertinggi dibandingkan dengan pemberian 30\% TKBK (484,0 g/ekor), $10 \%$ TKBK (452,5 g/ekor) dan tanpa 
pemberian TKBK (402 g/ekor).Bobot potong yang diperoleh dan pemberian TKBK (P0) merupakan bobot potong terendah diikuti dengan P1 dan P3. Hasil penelitian ini lebih tinggi dari hasil penelitian $\operatorname{Arief}(2000)$ yang mendapatkan bobot potong ayam kampung umur 6 minggu menggunakan pakan mengandung bungkil inti sawit dan enzim sebesar 272,65-297,02 g.

Hasil penelitian menunjukkan 20\% TKBK merupakan taraf optimal dari pemberian TKBK yang dapat direspons secara optimal oleh ayam kampung umur 7 minggu.Hal ini berimplikasi bahwa kandungan anti nutrisi (anti tripsin) dalam ransum tersubtitusi $30 \%$ TKBK dapat ditaksir dalam ayam kampung umur 7 minggu.Fenomena ini menunjukkan kadar protein kasar dalam ransum yang dapat direspons secara optimal oleh ayam kampung adalah $17,66 \%$.

Bobot potong ayam kampung dipengaruhi oleh beberapa faktor, umur merupakan faktor yang sangat mentukan bobot potong disamping kandungan nutrien dalam ransum. Menurut Nawawi (2011), untuk ayam kampung secara genetik masih alami sehingga kebutuhan pakannya cukup diklasifikasikan berdasarkan tingkat umurnya. Logikanya adalah bertambahnya umur akan terjadi bertambahnya bobot badan.

\section{Bobot dan Persentase Karkas}

Tabel 3 mununjukkan bahwa pemberian $10 \%$ TKBK (P1), $20 \%$ TKBK (P2) dan 30\% TKBK (P3) dalam ransum secara nyata meningkatkan bobot karkas ayam kampung umur 7 minggu. Bobot karkas (g/ekor) tertinggi diperoleh dari pemberian $20 \%$ TKBK (421.50 g/ekor), diikuti secara berurutan dengan pemberian $30 \%$ TKBK $(370,75$ g/ekor), $10 \%$ TKBK (331,50 g/ekor) dan tanpa Pemberian TKBK $(285,50$ g/ekor).

Hal ini menunjukkan pemberian 20\% TKBK merupakan taraf optimal dari pemberian TKBK yang dapat direspons secara optimal oleh ayam kampung umur 7 minggu.Fenomena ini searah dengan bobot potong yang diperoleh dari pemberian TKBK.Hasil penelitian ini lebih tinggi dibandingkan dari hasil penelitian Arief (2000) yang menggunakan ayam kampung umur 6 minggu dengan pemberian pakan mengandung bungkil inti sawit dan enzim yang mendapatkan bobot karkas sebesar 149,77-174,45 g.

Pemberian 10\% TKBK (P1), 20\% TKBK (P2) dan 30\% TKBK (P3) dalam ransum secara nyata meningkatkan persentase karkas tertinggi diperoleh dari pemberian $20 \%$ TKBK $(79,69 \%)$ dan 30\% TKBK $(76,64 \%)$ diikuti dengan pemberian $10 \%$ TKBK $(73,32 \%)$ dan tanpa Pemberian TKBK $(71,42 \%)$. Hal ini menunjukkan bahwa pemberian $20 \%$ TKBK dalam ransum merupakan Taraf optimal pemberian TKBK yang dapat direspons secara optimal oleh ayam kampung.Persentase karkas yang dihasilakan pada penelitianini tidak seiring dengan bobot karkas yang diperoleh dari pemberian $10 \%$ TKBK dan 30\% TKBK.

Kisaran rataan persentase karkas yang diperoleh dari penelitian ini sebesar 73,32\%-79,69\%. Hasil penelitian ini lebih tinggi dibandingkan dengan hasil penelitian (Resnawati, 2002) yang menggunakan $515 \%$ tepung cacing tanah dalam ransum ayam pedaging yaitu 68,0\%-71,80\%. Selanjutnya hasil penelitian ini lebih tinggi dibandingkan dengan hasil penelitian Indra dkk (2015) yang menggunakan ransum dengan 
bahanprotein kasar $17,51 \%$ pada ayam sentul $(79,69 \%$ dengan $51,10 \%)$.

Persentase karkas yang dihasilkan pada penelitian ini lebih tinggi dibandingkan dengan hasil penelitian Nelwida (2011), yang menggunakan 10$40 \%$ kulit ari biji kedelai fermentasi pada ayam pedaging pada level pemberian $10-30 \%$ persentase karkas yang dihasilkan dari pemberian TKBK lebih tinggi dibandingkan dengan pemberian kulit ari biji kedelai hasil fermentasi (65.84\%-67.64\%).

\section{Bobot dan Persentase Non Karkas}

Tabel 3 menunjukkan pemberian $10 \%$ TKBK, $20 \%$ TKBK dan 30\% TKBK dalam ransum tidak nyata $(\mathrm{P}>0,05)$ meningkatkan bobot non karkas dan persentase non karkas. Bobot non karkas (g/ekor) yang dihasilkan 117,0 (P1), 107,5 (P2), 113,25 (P3) dan 116,5 (P0).

Persentase non karkas (\%) yang diperoleh 23,36\% (P3), tidak berbeda dengan 26,68\% (P1) dan 25,58\% (P0). Selanjutnya, persentase non karkas $(\%)$ yang diperoleh $20,31 \% \quad(\mathrm{P} 2)$ tidak berbeda dengan $23,36 \%$ (P3). Hal ini menunjukkan persentase non karkas paling rendah diperoleh dari pemberian $20 \%$ TKBK. Persentase non karkas tidak searah dengan persentase karkas. Hal ini mungkin disebabkan bobot non karkas tidak berubah dengan pemberian TKBK. Fenomena ini tren dari persentase non karkas tidak searah dengan bobot potong dari bobot karkas bahkan berbanding terbalik.

Bobot non karkas yang diperoleh dari penelitian ini lebih rendah dibandingkan dengan hasil penelitian Ginting (2014) yang menggunakan ayam umur 12 minggu dengan pakan $30 \%$ ampas sagu non fermentasi dalam ransum $(113,25$ g/ekor dibandingkan $255,75 \mathrm{~g}$ /ekor).

\section{Pengaruh Pemberian Tepung Kulit Biji Kedelai terhadap Potongan Karkas}

Potongan karkas yang diamati meliputi bobot dan persentase sayap dan punggung atas, bobot dan persentase dada,dan bobot dan persentase paha dan punggung bawah. Rataan potongan karkas ayam kampung umur 7 minggu disajikan pada Tabel 4.

Tabel4.Rataan potongan karkas ayam kampung dengan pemberian tepung kulit biji kedelai (TKBK).

\begin{tabular}{|c|c|c|c|c|}
\hline \multirow[b]{2}{*}{ Variabel } & \multicolumn{4}{|c|}{ Perlakuan } \\
\hline & $\begin{array}{c}\mathrm{P} 0(0 \%) \\
\text { TKBK }\end{array}$ & $\begin{array}{c}\text { P1(10\%) } \\
\text { TKBK }\end{array}$ & $\begin{array}{c}\mathrm{P} 2(20 \%) \\
\text { TKBK }\end{array}$ & $\begin{array}{c}\mathrm{P} 3(30 \%) \\
\text { TKBK }\end{array}$ \\
\hline \multicolumn{5}{|c|}{ Sayap \& punggung atas } \\
\hline Bobot (g/ekor) & $18.75^{\mathrm{b}}$ & $23.50^{\mathrm{a}}$ & $31.00^{\mathrm{a}}$ & $26.75^{\mathrm{a}}$ \\
\hline Persentase $(\%)$ & $4.59^{c}$ & $5.20^{\mathrm{b}}$ & $5.86^{\mathrm{a}}$ & $5.53^{\mathrm{ab}}$ \\
\hline \multicolumn{5}{|l|}{ Dada } \\
\hline Bobot (g/ekor) & $212.00^{c}$ & $224.25^{\mathrm{c}}$ & $298.00^{\mathrm{a}}$ & $267.00^{\mathrm{b}}$ \\
\hline Persentase (\%) & $52.73^{\mathrm{bc}}$ & $49.58^{\mathrm{c}}$ & $56.25^{\mathrm{a}}$ & $55.17^{\mathrm{ab}}$ \\
\hline \multicolumn{5}{|c|}{ Paha \& punggung bawah } \\
\hline Bobot (g/ekor) & $54.75^{\mathrm{c}}$ & $86.75^{\mathrm{a}}$ & $86.00^{\mathrm{ab}}$ & $77.00^{\mathrm{b}}$ \\
\hline Persentase (\%) & $19.15^{\mathrm{a}}$ & $16.22^{\mathrm{b}}$ & $15.92^{\mathrm{b}}$ & $13.61^{\mathrm{c}}$ \\
\hline
\end{tabular}

$(\mathrm{P}<0,05)$ 


\section{Bobot dan Persentase Bobot Sayap dan Punggung Atas}

Tabel 4 menunjukkan pemberian $10 \%$ TKBK (P1), 20\% TKBK (P2) dan $30 \%$ TKBK (P3) dalam ransum secara nyata meningkatkan bobot sayap dan punggung atas. Bobot sayap dan punggung atas yang diperoleh (g/ekor) 18.70 (P0), 23.50 (P1), 31.00 (P2) dan 26.75 (P3).

Tabel 4 menunjukkan persentase bobot sayap dan punggung atas (\%) yang diperoleh 4.59 (P0), 5.20 (P1), 5.86 (P2) dan 5.53 (P3). Pemberian $10 \%$ TKBK, 20\% TKBK dan 30\% TKBK meningkatkan secara nyata $(\mathrm{P}<0,05)$ persentase bobot sayap dan punggung atas. Hasil peneltian ini lebih rendah bila dibandingkan dengan hasil penelitian Ruza (2004) yang menggunakan ayam umur 14 minggu diperoleh persentase sayap sebesar 9,51-10,29\% secara terpisah persentase punggung diperoleh sebesar 14,96$17,41 \%$.

Tren peningkatan bobot dan persentase bobot sayap+punggung tidak searah dengan tren peningkatan bobot hidup yang diperoleh dari pemberian TKBK. Bila dihubungkan dengan komposisi kimia ransum maka kadar protein kasar (PK) sekitar 17\% dalam ransum diduga merupakan kadar PK dapat memenuhi kebutuhan hidup dan produksi pada ayam kampung umur 7 minggu.

\section{Bobot dan Persentase Bobot Dada}

Tabel menunjukkan pemberian $20 \%$ TKBK dan 30\% TKBK dalam ransum secara nyata meningkatkan bobot dada, tetapi pemberian 10\% TKBK tidak dapat meningkatkan bobot dada ayam umur 7 minggu. Bobot dada (g/ekor) yang diperoleh dari pemberian TKBK yaitu 224.25 (P1), 298,00 (P2), 267.00 (P3) dan tanpa pemberian TKBK
212.00 (P0). Hasil penelitian ini menunjukkan taraf pemberian $20 \%$ TKBK dalam ransum merupakan tarafoptimal yang direspons untuk menghasilkan bobot dada optimal pada ayam kampung umur 7 minggu.

Persentase bobot dada (\%) yang diperoleh dari pemberian TKBK yaitu 49.58 (P1), 56.25 (P2), 51.17 (P3) dan tanpa pemberian TKBK 52.73 (P0).Hasil penelitian ini menunjukkan pemberian $20 \%$ TKBK merupakan taraf optimal yang dapat direspons secara optimal untuk memperoleh persentase bobot dada ayam kampung umur 7 minggu. Hasil penelitian ini lebih tinggi bila dibandingkan dari hasil penelitian Santosa (2004) yang mendapatkan persentase dada ayam kampung umur 9 minggu sebesar 25,57-26,34\%.

\section{Bobot dan Persentase Bobot Paha dan Punggug Bawah}

Tabel 4 menunjukkan pemberian $10 \%$ TKBK, 30\% TKBK dalam ransum secara nyata meningkatkan bobot paha dan punggung bawah ayam kampung umur 7 minggu.Bobot paha dan punggung bawah (g/ekor) yang diperoleh dari pemberian TKBK yaitu 54.75 (P0), $86.75(\mathrm{P} 1), 86.00(\mathrm{P} 2)$ dan 77.00 (P3).

Persentase bobot paha dan punggung bawah (\%) yang diperoleh dari pemberian TKBK yaitu 19.15 (P0), 16.22 (P1), 15,92 (P2) dan 13.61 (P3). Hasil penelitian ini menunjukkan pemberian $10 \%-30 \%$ TKBK dalam ransum secara nyata menurunkan persentase bobot paha dan punggung bawah.Semakin tinggi taraf pemberian TKBK maka semakin rendah persentase bobot paha dan punggung bawah yang diperoleh pada ayam kampung umur 7 minggu. Hasil penelitian ini lebih rendah dari hasil penelitian Santosa (2004) yang mendapatkan persentase paha sebesar 31,73-31,75\%. 
Pengaruh Pemberian Tepung Kulit Biji Kedelai dalam Ransum terhadap Performans Non Karkas Ayam Kampung

Performans non karkas ditunjukkan oleh beberapa bagian organ dalam diantaranya giblet.Giblet pada ayam merupakan organ yang dapat dimakan oleh manusia.Giblet terdiri atas rempela, hati dan jantung.Ketiga organ tersebut merupakan giblet yang biasa dikonsumsi oleh masyarakat Indonesia.Rataan bobot dan persentase rempela, hati dan jantung yang diperoleh dari ayam kampung dengan pemberian 10\%-30\% TKBK dalam ransum disajikan pada Tabel 5.

Tabel 5.Rataan Bobot dan Persentase giblet Ayam Kampung dengan Pemberian Tepung Kulit Biji Kedelai (TKBK) dalam Ransum.

\begin{tabular}{|c|c|c|c|c|}
\hline \multirow[b]{2}{*}{ Variabel } & \multicolumn{4}{|c|}{ Perlakuan } \\
\hline & $\begin{array}{c}\mathrm{P} 0 \\
(0 \%) \mathrm{TKBK} \\
\end{array}$ & $\begin{array}{c}\mathrm{P} 1 \\
(10 \%) \mathrm{TKBK}\end{array}$ & $\begin{array}{c}\mathrm{P} 2 \\
(20 \%) \mathrm{TKBK} \\
\end{array}$ & $\begin{array}{c}\mathrm{P} 3 \\
(30 \%) \mathrm{TKBK}\end{array}$ \\
\hline \multicolumn{5}{|l|}{ Total Giblet } \\
\hline Bobot (g/ekor) & $28.00^{\mathrm{b}}$ & $33.50^{\mathrm{a}}$ & $35.00^{\mathrm{a}}$ & $28.50^{\mathrm{b}}$ \\
\hline Persentase(\%) & $6.96^{\mathrm{a}}$ & $7.41^{\mathrm{a}}$ & $6.63^{\mathrm{ab}}$ & $5.89^{\mathrm{b}}$ \\
\hline \multicolumn{5}{|l|}{ Rempela } \\
\hline Bobot (g/ekor) & 14.00 & 18.00 & 17.50 & 14.50 \\
\hline Persentase (\%) & 3.71 & 3.99 & 3.31 & 3.00 \\
\hline \multicolumn{5}{|l|}{ Hati } \\
\hline Bobot (g/ekor) & 12.00 & 13.50 & 15.00 & 12.00 \\
\hline Persentase (\%) & 2.98 & 2.97 & 2.85 & 2.48 \\
\hline \multicolumn{5}{|l|}{ Jantung } \\
\hline Bobot (g/ekor) & 2.00 & 2.00 & 2.50 & 2.00 \\
\hline Persentase (\%) & 0.50 & 0.45 & 0.47 & 0.42 \\
\hline
\end{tabular}

\section{Bobot dan Persentase Bobot Total Giblet}

Tabel 5 menunjukkan pemberian 10$30 \%$ TKBK dalam ransum secara nyata meningkatkan bobot total giblet tetapi pemberian $30 \%$ TKBK dalam ransum tidak berbeda dengan tanpa pemberian TKBK. Bobot total giblet (g/ekor) yang diperoleh 28.00 (P0), 33.50 (P1), 35.00 (P2) dan 28.50 (P3).

Hasil penelitian ini menunjukkan tren organ dalam tidak sama dengan tren persentase organ dalam. Perbedaan ini mengindikasikkan pemberian TKBK dengan taraf berbeda dampaknya terhadap bobot organ dalam yang menunjukkan proses metabolism nutrien berbeda dengan persentasenya yang menunjukkan besar rasio antar bobot organ dalam dengan bobot hidup.

Hasil penelitian ini lebih tinggi dari hasil penelitian Arief (2000) yang mendapatkan bobot hati ayam kampung umur 6 minggu sebesar 19,8-22,24 g. Persentase total giblet (\%) yang diperoleh sebesar dari pemberian $10 \%$ $20 \%$ TKBK dalam ransum tidak berbeda dengan tanpa pemberian TKBK.

\section{Bobot dan Persentase Bobot Rempela}

Tabel menunjukkan pengaruh pemberian 10\%-30\% TKBK dalam ransum tidak nyata berbeda terhadap 
bobot rempela.Bobot rempela (g/ekor) yang diperoleh 14.00 (P0), 18.00 (P1), 17.50(P2) dan 14.50 (P3). Hasil penelitian ini menunjukkan pemberian 10-30\% TKBK dalam ransum tidak mengganggu proses pencernaan secara maksimal dalam rempela. Hal ini berimplikasi proses pencernaan ransum berbeda protein kasar sekitar 14\%-20\% tidak berbeda dan tidak berdampak negatif terhadap bobot anatomi rempela. Hasil penelitian ini lebih tinggi dibandingkan dengan hasil penelitian Arif (2000) yang memperoleh bobot rempela sebesar 9,08-11,13 g, perbedaan hasil yang diperoleh karena umur ayam kampung yang tidak sama.

Pengaruh pemberian 10\%-30\% TKBK tidak berbeda nyata terhadap persentase bobot rempela. Persentase bobot rempela (\%) yang diperoleh 3,71 (P0), 3,99 (P1), $3.31(\mathrm{P} 2)$ dan $3.00(\mathrm{P} 3)$. Hasil penelitian ini lebih tinggi dibandingkan dengan hasil penelitian Resnawati (2002), yang menggunakan tepung cacing tanah untuk menggantikan tepung ikan 0-15\% dalam ransum (3.00\%-3.99\% dibandingkan $1.53 \%-1.67 \%$ ) perbedaan ini menunjukkan kadar serat kasar dalam ransum mempengaruhi persentase bobot rempela.

\section{Bobot dan Persentase Bobot Hati}

Tabel menunjukkan pengaruh pemberian 10\%-30\% TKBK dalam ransum tidak nyata berbeda terhadap bobot hati ayam kampung umur 7 minggu.Bobot hati (g/ekor) yang diperoleh 12.00 (P0), 13.50 (P1), 15.00 P2) dan 12.00 (P3). Hal ini menunjukkan pemberian 10\%-30\% TKBK dalam ransum tidak menimbulkan perubahan anatomi hati mengalami perubahan.Hasil penelitian ini lebih tinggi dari hasil penelitian Arief (2000) yang mendapatkan bobot hati sebesar 8,03-9,43 g.
Pengaruh pemberian 10\%-30\% TKBK dalam ransum tidak berbeda terhadap persentase hati ayam kampung.Persentase hati (\%) yang diperoleh 2.98 (P0), 2.97 (P1), 2.85 (P2) dan 2.48 (P3).Hasil penelitian lebih tinggi dibandingkan dengan hasil penelitian Resnawati (2002), yang menggunakan tepung cacing tanah sebagai pengganti tepung ikan $(2.48 \%$ $2.98 \%$ dibandingkan $1.70 \%-2.30 \%$ ). Namun lebih rendah dari hasil penelitian Arief (2000) yang mendapatkan persentase hari sebesar $2,70-3,46 \%$

\section{Bobot dan Persentase Jantung}

Tabel menunjukkan pengaruh pemberian 10\%-30\% TKBK dalam ransum tidak nyata berbeda terhadap bobot jantung ayam kampung umur 7 minggu.Bobot jantung (g/ekor) yang diperoleh 2.00 (P0), 2.00 (P1), 2.50 (P2) dan 2.00 (P3).Hal ini menunjukkan pemberian 10\%-30\% TKBK dalam ransum tidak mengakibatkan peningkatan aktifitas otot jantung untuk memompa darah keseluruh tubuh. Hasil penelitian ini sejalan dengan hasil penelitian Arief (2000) yang mendapatkan Bobot Jantung sebesar $1,68-2,15 \mathrm{~g}$.

Pengaruh pemberian 10\%-30\% TKBK dalam ransum tidak berbeda nyata terhadap persentase bobot jantung. Persentase bobot jantung (\%) yang diperoleh $0,50(\mathrm{P} 0), 0.45$ (P1), 0.47 (P2) dan 0.42 (P3). Hasil menunjukkan kondisi jantung ayam kampung dengan pemberian 10\%-30\% TKBK adalah normal. Menurut Resnawati (2002) persentase bobot jantung yang normal pada ayam pedaging berkisar $0.41 \%-1.42 \%$. Hasil penelitian ini tidak berbeda dari hasil penelitian Arief (2000) yang diperoleh persentase jantung sebesar 0,62-0,77\% . 


\section{KESIMPULAN}

Berdasarkan hasil penelitian dan pembahasan maka dapat disimpulkan bahwa :

1. Pemberian ransum komersial tersubtitusi 10\%-30\% tepung kulit biji kedelai (TKBK) pada ayam kampung sampai umur 7 minggu dapat meningkatkan performans karkas meliputi bobot hidup, bobot karkas, persentase bobot karkas, bobot sayap, persentase bobot sayap dan bobot paha, serta bobot giblet.

2. Pemberian ransum komersial tersubtitusi 10\%-30\% tepung kulit biji kedelai (TKBK) pada ayam kampung sampai umur 7 minggu menurunkan persentase bobot paha.

3. Pemberian ransum komersial tersubtitusi 10\%-30\% tepung kulit biji kedelai (TKBK) pada ayam kampung sampai umur 7 minggu tidak berpengaruh secara nyata terhadap bobot dan persentase bobot rempela, hati dan jantung.

\section{DAFTAR PUSTAKA}

Arief, D., A. 2000. Evaluasi ransum yang menggunakan kombinasi pollard dan dukweed terhadap persetase berat karkas, bulu, organ dalam, lemak abdominal, panjang usus dan sekum ayam kampung. Skripsi. Fakultas Peternakan. IPB. Bogor.

Candrawati, $\quad$ D.P.M.A. 1999. "Pendugaan kebutuhan engergi dan protein ayam Kampung umur 0-8 minggu" (tesis). Bogor. Institut Pertanian Bogor.

Gaspers, V. 1994.Metode Perancangan Percobaan untuk Ilmu-ilmu Pertanian, Ilmu-ilmu Tehnik dan Biologi.Armico. Bandung.
Gunawan, A. S. A., Subandiyono, dan Pinandoyo. 2014. Pengaruh vitamin $\mathrm{C}$ dalam pakan buatan terhadap tingkat konsumsi pakan dan pertumbuhan ikan nila merah (O. niloticus). Journal of Aquaculture Management and Technology. 3 (4):191-198.

Hafid, H. 2011. Pengantar Evaluasi Karkas. Cetakan Pertama. Penerbit Unhalu Press, Kendari

Hanafiah, K. A. 2008. Rancangan Percobaan Teori dan Aplikasi. Edisi Ketiga PT. Raja Grafindo Persda, Jakarta.

Husmaini. 2000. Pengaruh peningkatan level protein dan energi ransum saat Refeeding terhadap performans ayam buras. Jurnal Peternakan dan Lingkungan. Vol. $6(01)$.

Indarto. N. 2010. Sukses dan Untung Besar Beternak Ayam

Broiler.Lumine Books.Yogyakarta

Indra.W., Tanwiriah.W., Widjastuti.T., 2015.Bobot Potong, Karkas, Dan Income Over Feed Cost Ayam Sentul Jantan Pada Berbagai Umur Potong Slaughter Weights, Carcass And Income Over Feed Cost Males Sentul Chicken At Different Slaughter Age Fakultas Peternakan Universitas

Padjadjaran;file:///C:/Users/lenovo/Ap pData/Local/Temp/6944-10941-1-

SM.pdfe-mail:wicaindra @ gmail.com.

Iswanto, H. 2008. Ayam Kampung Pedaging. Agromedia Pustaka. Jakarta.

Koswara, S. 2009. Pengolahan Unggas. EbookPangan.com. 
Margawati, E.T. 1989. Efesiensi penggunaan ransum oleh ayam kampung jantan Dan betina pada periode pertumbuhan. Prosiding Seminar Nosional tentang unggas lokal. 28 Sept. Fakultas Peternakan UNDIP. Semarang. Hal.127-132.

Mi'un, M. A. 2008. Heritabilitas beberapa ukuran tubuh ayam kampung. Jurnal Ilmu Peternakan. FPPK.UNIPA. Vol. 3 no. 1 (119).

Murtidjo.B.A. 2003.Pemotongan dan Penanganan Daging Ayam. Kanisius, Yogyakarta.

Niswati. Z. A., Safitri. A., Santoso. I., 2009.Fermentasi Janggel Jagung dan Kulit Ari Biji Kedelai sebagai Pakan Ternak Ayam Kampung yang Murah, Mudah, dan Bergizi Tinggi Pemerintah Kabupaten Ponorogo

Dinas Pendidikan

Nasional.Ponorogo.

Nurdiani, 2005. Pengaruh penambahan neubro pada level yang berbeda terhadap Penampilan ayam kampung fase stater. Skripsi.Fakultas

Pertanian.Universitas Halu Oleo. Kendari.

Pagala, M.A., Muladno, C.Sumantri \& S. Murtini. 2013.Association of $\mathrm{Mx}$ Gene Genotype with Antiviral andProduction Traits in Tolaki Chicken.Int. J. Poult Sci. 12 (12): 735-739.

Pagala, MA, AM.Tasse, N.Ulupi. 2015. Association of cGH EcoRV Gene with Production in Tolaki Chicken. IJSBAR. 24(7):88-95.

Nelwida, 2011.Pengaruh Pemberian Kulit Ari Biji Kedelai Hasil
Fermentasi dengan Pergillus Niger dalam Ransum terhadap Bobot Karkas Ayam Pedaging. Ilmu-ilmu Peternakan XIV (1) : 23-29.

Resnawati. H. 2004. Bobot Potongan Karkas Dan Lemak Abdomen Ayam Ras Pedaging Yang Diberi Ransum Mengandung Tepung Cacing Tanah.Seminar Nasional Teknologi Peternakan dan Veteriner.Jurnal.

Risnajati. D. 2012. Perbandingan Bobot Akhir, Bobot Karkas Dan Presentase Karkas Berbagai Strain Broiler. Sains Peternakan. 10 (1) : 11-14.

Ruza, R., P., 2004. Pengaruh pemberian tetrasiklin dan kopi dalam ransum berenergi metabolisme 3.000 $\mathrm{Kkal} / \mathrm{kg}$ terhadap persentase karkas, organ dalam dan potongan komersial ayam kampung.Skripsi. Fakultas Peternakan. IPB. Bogor.

Santosa, D., H., 2004. Persentase karkas dan potongan komersial karkas ayam kampung dengan pemberian pakan mengandung bungkil inti sawit dan enzim.Skripsi. Fakultas Peternakan. IPB. Bogor.

Soeparno. 2005. Ilmu dan Teknologi Daging. UGM Press. Jogjakarta.

Steel, R.G.D. dan J.H. Torrie. 1993. Prinsip dan Prosedur Statistika. Suatu Pendekatan Biometrik. PT. Gramedia Pustaka Utara, Jakarta.

Supraptini, M. S. 1985. "Pengkajian Sifat-sifat Produksi Ayam Kampung serta Persilangannya dengan Rhode Island Red" (Disertasi) bogor : Institut Pertanian Bogor. 
Tarigan, R., S. Osfar, dan H.D. Irfan, 2015.Pengaruh Penambahan Probiotik Selulolitik (Cellulomonas sp) dalam Pakan terhadap Kualitas Karkas, Lemak Abdominal dan Berat Organ Dalam ayam Pedaging. Universitas Brawijaya. Malang. Jurnal; 1-10.

Williamson, G. and W. J. A. Payne. 1993. Pengantar Peternakan di Daerah Tropis. Terjemahan oleh: IGN Djiwa Darmadja. Gadjah Mada University Press. Yogyakarta.
Yefri, W. 2006. Penggemukan Domba Ekor Tipis Dengan Pemberian Pakan Kulit Ari Kacang Kedelai (Ampas Tempe) Dan Rumput Lapang. Fakultas Peternakan. IPB. Bogor

Yuanita.I., S. Murtini, dan I. Rahayu. 2009. Performa dan Kualitas Ayam Pedaging yang diberi Pakan Tambahan Ampas Buah Merah (PandausConoideus). Seminar Nasional Teknologi Peternakan dan Veteriner, Jurnal. 